\section{Establishment and Lateral Growth of Glyphosate-resistant Creeping Bentgrass in Bare Soil}

\author{
D.S. Gardner ${ }^{1}$, E.K. Nelson ${ }^{2}$, M.A. Waldecker ${ }^{3}$, and W.R. Tarter ${ }^{4}$
}

ADDITIONAL INDEX WORDs. competition, genetically modified organism, GMO, turfgrass, Agrostis stolonifera, Agrostis palustris, CP4, EPSPS

\begin{abstract}
Summary. Plant establishment and lateral growth of glyphosate-resistant creeping bentgrass [Agrostis stolonifera (synonym A. palustris)] were assessed to determine if the insertion of the construct conferring herbicide tolerance affected establishment rate or aggressiveness characteristics in unmowed situations. Field studies were carried out in Michigan, Illinois, Ohio, and Oregon in 2000 and 2001 to examine the relative lateral growth of several transformed lines of creeping bentgrass, non-transformed controls, and cultivar standards. Vegetative plugs of creeping bentgrass were transplanted into replicated bare-soil plots and irrigated as needed to prevent moisture stress for an initial 6-week period. Measurements of maximum and minimum stolon spread, percent cover, and stand density for each entry were made in the field at all locations during 2000 and 2001. Few statistical differences $(P=0.05)$ in establishment and lateral growth were observed between individual lines of transgenic creeping bentgrass, non-transformed control lines, and standard cultivars and over a 15- to 18 -month period. Overall, lateral growth and establishment rate of transgenic lines were similar to their non-transformed parent and the standard cultivars tested. Transgenic creeping bentgrass lines should have no greater potential for lateral growth than conventional creeping bentgrass cultivars currently in use.
\end{abstract}

$\mathrm{C}$ reeping bentgrass is a perennial, stoloniferous cool season grass predominantly used for recreational turfgrass on golf course greens, tees, and fairways in cool season turfgrass growing regions of the United States (Bradshaw, 1958; Hitchcock, 1950). Various weedy grasses, including annual bluegrass (Poa annua), are serious management problems in creeping bentgrass fairways and putting greens (Turgeon, 2002). Current potential controls for annual bluegrass in creeping bentgrass greens require multiple treatments and have not been completely effective in practice (Turgeon, 2002). Creeping bentgrass is sensitive to many herbicides used in an attempt to control weeds in creeping bentgrass (Dernoeden, 2000; Johnson et al., 1989). Genetically engineered

Journal Article Number HCS 05-03.

${ }^{1}$ Assistant Professor, Dept. of Horticulture and Crop Science, 2021 Coffey Road, The Ohio State University, Columbus, OH 43210-1086. Corresponding author; e-mail: gardner.254@osu.edu

${ }^{2}$ Research Scientist, The Scotts Company, 14111 Scottslawn Rd., Marysville, OH 43041.

${ }^{3}$ Research Scientist, Agsearch Company, 1705 Wilson Street, Conklin, MI 49403

${ }^{4}$ Research Scientist, Alvey Ag Research, 19300 Marydale Road, Caryle, IL 62231. creeping bentgrass cultivars have been developed that are resistant to glyphosate, a non-selective herbicide, via the heterologous expression of a gene from the CP4 strain of Agrobacterium sp. encoding for a glyphosate-resistant form of 5-enolpyruvyl-shikimate-3phosphate synthase (EPSPS). EPSPS catalyzes the formation of EPSP from shikimate 3-phosphate and phosphoenolpyruvate. Glyphosate inhibits this reaction by interfering with binding of PEP (Thompson et al., 1987). The gene and construct are similar to that used to modify other glyphosate-resistant crops, such as soybean (Glycine max) (Padgette et al., 1995). This same gene has been used in the production of glyphosate-resistant corn ( $\mathrm{Zea}$ mays), soybean, and several other crops (James, 1997, 1998).

Creeping bentgrass is a native turfgrass species, as well as introduced from Europe (Hitchcock, 1950; U.S.
Department of Agriculture, 2004). Many introduced turfgrass species have become naturalized along fence rows and roadsides adjacent to production fields. However, most of these turfgrass species, including creeping bentgrass, are not considered significant weed problems in production agriculture because they are relatively slow growing, small in stature, and quickly out-competed by most crop plants (Johnson and Riordan, 1999), and other competitive conditions. Creeping bentgrass has limited ability to establish from seed under competitive conditions. (Kendrick and Danneberger, 2002; Jonsdottir, 1991). Adoption of glyphosate-resistant creeping bentgrass could potentially simplify and improve the control of grass and broadleaf weeds that invade golf course turfgrass. However, there are concerns that glyphosate-resistant creeping bentgrass might become a weed in glyphosate-resistant crop fields or natural areas. However, glyphosate (Roundup Pro; Monsanto Co., St. Louis) promises only partial control of non-trasnsgenic bentgrass, and several glyphosate alternatives for control of bentgrasses are available (Colquhoun et al., 2001; Dant, 2005; Hart et al., 2005). Creeping bentgrass, when managed at the low mowing heights typical of golf course maintenance, does not possess many characteristics of an ideal weed (Baker, 1965). Weediness is usually considered a multigenic trait and, therefore, it is unlikely that the introduction of a herbicide resistance gene into turfgrass could result in a new problem weed (Banks et al., 2003; Johnson and Riordan, 1999). Previous research has suggested that the introduction of an herbicide resistance gene may result in a competitive disadvantage in the absence of the herbicide (Bergelson et al., 1996).

Previous research has estimated the comparative development and potential weediness of transgenic vs. conventional creeping bentgrass when introduced into turfgrass grown in a variety of habitats and under a range of climatic conditions (Gardner et al.,

\begin{tabular}{llll}
\hline $\begin{array}{l}\text { Units } \\
\begin{array}{l}\text { To convert U.S. to SI, } \\
\text { multiply by }\end{array}\end{array}$ & U.S. unit & SI unit & $\begin{array}{l}\text { To convert SI to U.S., } \\
\text { multiply by }\end{array}$ \\
\hline 0.3048 & $\mathrm{ft}$ & $\mathrm{m}$ & 3.2808 \\
2.54 & inch $(\mathrm{es})$ & $\mathrm{cm}$ & 0.3937 \\
48.8243 & $\mathrm{lb} / 1000 \mathrm{ft}^{2}$ & $\mathrm{~kg} \cdot \mathrm{ha}^{-1}$ & 0.0205 \\
1.1209 & $\mathrm{lb} / \mathrm{acre}$ & $\mathrm{kg} \cdot \mathrm{ha}^{-1}$ & 0.8922 \\
1.1692 & $\mathrm{pt} / \mathrm{acre}$ & $\mathrm{L} \cdot \mathrm{ha}^{-1}$ & 0.8553
\end{tabular}


2003). The objective of this study, however, was to determine if glyphosateresistant creeping bentgrass differed from conventional creeping bentgrass in its relative rates of establishment and vegetative development as a colonizer in a non-competitive environment.

\section{Materials and methods}

Glyphosate-resistant creeping bentgrass plant material (ASR368) was a cloned R0 (originally transformed) plant established from stolon nodes and grown in 1-2/3-inch-diameter peat pellets (Jiffy Products of America Inc., Batavia, Ill.) in a cold frame in Oregon. All plants were cloned at the same time to maintain age equivalence. Three plants were established on each plot. The non-transformed tissue culture control (B99061R) plants were cloned from a single genotype. The conventional creeping bentgrass cultivars ('Penncross', 'Crenshaw', and 'Penn A-4') were propagated from single stolon nodes and for each cultivar there were three genotypes planted on a plot. The plants were irrigated to prevent drought stress and fertilized to eliminate visible nutrient deficiencies. Plants were maintained at a height of $1 / 2$ inch.

Field studies were established on bare-soil plots in July 2000 at four locations: Marysville, Ohio (lat. $83^{\circ} 22^{\prime} \mathrm{N}$, long. $40^{\circ} 16^{\prime} \mathrm{W}$ ); Conklin, Mich. (lat. $85^{\circ} 52^{\prime} \mathrm{N}$, long. $\left.43^{\circ} 07^{\prime} \mathrm{W}\right)$; Carlyle, Ill. (lat. $89^{\circ} 22^{\prime} \mathrm{N}$, long. $38^{\circ} 36^{\prime} \mathrm{W}$ ); and Gervais, Ore. (lat. $122^{\circ} 56^{\prime} \mathrm{N}$, long. $\left.45^{\circ} 7^{\prime} \mathrm{W}\right)$. Each field location had three replicate plots for each entry in a randomized complete-block design. Each plot consisted of a $5 \times 3-\mathrm{ft}$ area populated with three plants of a single entry. Each plot was separated from other plots by 15 - $\mathrm{ft}$ borders within replications and $4.6-\mathrm{m}$ borders between replications. Soil cores ( $1-1 / 3$ inches in diameter and 1 to $1-1 / 2$ inches deep) were removed from the original area on 2 - to 3 - $\mathrm{ft}$ centers with an auger bit. Creeping bentgrass plugs of 2 -inch diameter were transplanted directly into the core holes so that the plant crowns were at or slightly below the soil surface. The duration of the study was based on previously published reports concerning creeping bentgrass population dynamics which allowed for data collection for two complete growing seasons (Cattani et al., 1991; Jonsdottir, 1991).

Plots were irrigated as needed to prevent drought stress during an initial 6-week establishment phase. Plots were monitored and individual seed heads were manually clipped to preclude any pollen development. Plants were not mowed for the duration of these experiments. Nitrogen (0.5-0.75 $\mathrm{lb} / 1000 \mathrm{ft}^{2}$ per month during active growth), potassium, and phosphorus were applied as needed to compensate for visual deficiency symptoms. Constant pressure of weed invasion in the plots was reduced with chemical and mechanical management. The amine salts of 2,4-D, MCPP, and dicamba (3 pt/acre, Trimec Bentgrass Formula; PBI Gordon Inc., Kansas City, Mo.) were applied as necessary at label rates to control broadleaf weeds. Pendimethalin $(0.75-1.5 \mathrm{lb} /$ acre a.i., Scott's Weed Grass Control 60WP; The Scotts Co., Marysville, Ohio) and dithiopyr $(0.25 \mathrm{lb} /$ acre a.i., Dimension $1 \mathrm{EC}$; Dow Agrosciences LLC, Indianapolis) were applied as necessary at label rates for control of grassy weeds. These herbicides may have affected stolon establishment rate, but they likely affected all lines equally. Plots were also hand cultivated as necessary to control weeds.

Evaluations during 2000 and early 2001 consisted of measuring the diameter of each transplanted plant. The longest stolon emerging $(\max )$ as well as the smallest stolon emerging (min) was measured once per month. Additional evaluations during 2001 were made by visually observing the percent groundcover and turfgrass density of each entry in each plot. This change facilitated a more rapid and direct assessment of development as plants within each plot had grown into one another, precluding stolon length measure.

Studies were conducted at four locations. The data were analyzed using the general linear model procedure in SAS (SAS Institute Inc., Cary, N.C.). The mean length of the longest stolons $(\max )$ and shortest stolons ( $\mathrm{min}$ ) within each plot for each entry were calculated at each observation date. Means were based on nine observations per genotype (mean of two measurements on each of three plants of each line or cultivar per plot in three replications). Also recorded were the range of values observed for each mean. Stolon vigor was defined as the rate of lateral growth since the previous month. Later season evaluations for percent groundcover and turfgrass density ( $1-9$ scale, $9=$ greatest shoots per unit area) were averaged for each creeping bentgrass entry per observation date per location. Means were separated using Fisher's protected least significant difference test at $P=0.05$ (SAS Institute Inc.).

\section{Results and discussion}

Analysis of variance with all locations combined revealed statistically significant location effects. Data were analyzed separately for each location. In most cases, glyphosate-resistant line ASR368 displayed no increase in lateral growth rate compared to traditional creeping bentgrass varieties or the non-transformed control.

In Illinois, significant differences between genotypes when measuring stolon extension were detected only during Sept. $2000(P=0.023)$ and Apr. 2001 $(P=0.019)$ when 'Penn A-4' was significantly smaller than all other plant genotypes (Table 1).

Table 1. Stolon length of a glyphosate-resistant line of creeping bentgrass (ASR368), its non-transformed control (B99061R), and creeping bentgrass reference cultivars in Illinois from Aug. 2000 to Apr. 2001. Means were calculated from the maximum and minimum values of three plugs per replicate $(n=9)$.

\begin{tabular}{|c|c|c|c|c|c|}
\hline \multirow[b]{2}{*}{ Cultivar or line } & \multicolumn{4}{|c|}{2000} & \multirow{2}{*}{$\begin{array}{l}2001 \\
\text { April }\end{array}$} \\
\hline & August & September & October & November & \\
\hline & \multicolumn{5}{|c|}{ - Stolon length $(\mathrm{cm})^{\mathrm{z}}-\ldots$} \\
\hline Crenshaw & 29.7 & $39.0 a^{y}$ & 39.7 & 43.0 & $35.3 \mathrm{a}$ \\
\hline Penn A-4 & 24.7 & $22.3 b$ & 30.3 & 39.7 & $24.7 \mathrm{~b}$ \\
\hline Penncross & 33.7 & $42.0 \mathrm{a}$ & 44.0 & 50.0 & $42.0 \mathrm{a}$ \\
\hline B99061R & 30.0 & $38.0 \mathrm{a}$ & 36.7 & 37.7 & $35.0 \mathrm{a}$ \\
\hline ASR368 & 30.3 & $35.0 \mathrm{a}$ & 35.3 & 37.3 & $33.7 \mathrm{a}$ \\
\hline $\operatorname{LSD}_{(0.05)}$ & NS & 10.9 & NS & NS & 8.6 \\
\hline $\mathrm{CV}$ & 13.9 & 16.4 & 17.9 & 20.6 & 13.3 \\
\hline
\end{tabular}

${ }^{\mathrm{z}} 1 \mathrm{~cm}=0.3937$ inch.

'Means followed by the same letter are not significantly different according to Fisher's protected least significant difference test at $P=0.05 \operatorname{LSD}_{(0.05)}$

${ }^{\mathrm{NS} N o n s i g n i f i c a n t}$ according to $\mathrm{LSD}_{(0.05)} ; \mathrm{CV}=$ coefficient of variation. 
Table 2. Percent ground cover and turfgrass density of a glyphosate-resistant line of creeping bentgrass (ASR368), its nontransformed control (B99061R), and creeping bentgrass reference cultivars in Illinois from May to Aug. 2001 ( $\mathrm{n}=3$ ).

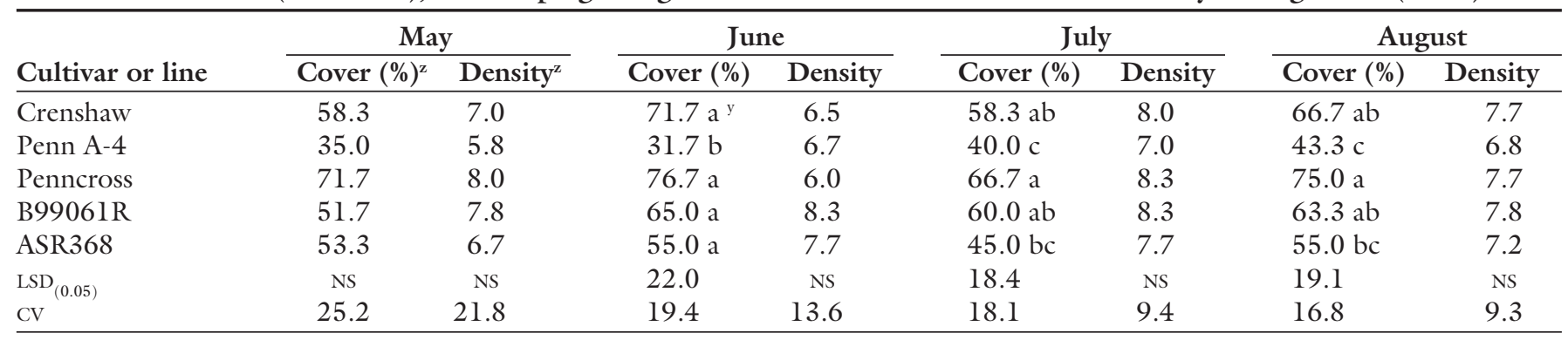

${ }^{2}$ Cover $(\%)=$ visual estimate of percent ground cover within a plot. Density determined on a $1-9$ scale with $1=$ low shoot number per unit area and $9=$ high shoot number per unit area.

y Means followed by the same letter are not significantly different according to Fisher's protected least significant difference test at $P=0.05$ [LSD ${ }_{(0.05)}$.

${ }^{\mathrm{NS}}$ Nonsignificant according to $\mathrm{LSD}_{(0.05)} ; \mathrm{CV}=$ coefficient of variation.

Stolon length for ASR368 was not significantly different from B99061R or 'Penncross' and 'Crenshaw' reference cultivars at any measurement date. ASR 368 stolon length was always within the range of measured values on non-transformed reference cultivars and B99061R. Significant differences between genotypes were detected in Illinois for percentage of plot cover during June, July, and Aug. 2001 ( $P$ $=0.010,0.049,0.040$, respectively; Table 2). Plot coverage of 'Penn A-4' was significantly less than that of the other genotypes that were similar to each other during June, but was not significantly different from ASR368 on any other date. Plot coverage of 'Penncross' was higher than ASR368 during July and Aug. 2001. ASR368 was not significantly different from other genotypes and was intermediate to non-transformed genotypes for percentage of plot cover and shoot density during all measurement dates.

In Michigan, no differences in relative growth were observed among any of the lines in 2000 and 2001
(Tables 3 and 4). Maximum stolon length, percentage of plot coverage, and plant shoot density for ASR368 were numerically less than that of control plant genotypes measured during two growing seasons from Aug. 2000 through Oct. 2001.

In Ohio, relative growth of ASR368 as measured by percent cover

was similar to its non-transformed parent and cultivar Penn A-4 and significantly lower than that of 'Crenshaw' or 'Penncross' in July, Aug., and Sept. 2001. Estimates of turfgrass stand density were also significantly lower for ASR368 compared to 'Crenshaw' and 'Penncross' in Aug. and Sept. 2001. Transgenic event ASR368 did not

Table 3. Stolon length of a glyphosate-resistant line of creeping bentgrass (ASR368), its non-transformed control (B99061R), and creeping bentgrass reference cultivars in Michigan from Aug. 2000 to Mar. 2001. Means were calculated from the maximum and minimum values of three plugs per replicate $(\mathbf{n}=9)$.

\begin{tabular}{|c|c|c|c|c|c|c|}
\hline \multirow[b]{2}{*}{ Cultivar or line } & \multicolumn{4}{|c|}{2000} & \multicolumn{2}{|c|}{2001} \\
\hline & August & September & October & November & February & March \\
\hline & & & Stolon ler & gth $(\mathrm{cm})^{\mathrm{z}_{-}}$ & & \\
\hline Crenshaw & 42.3 & 53.0 & 59.0 & 61.3 & 57.0 & 61.3 \\
\hline Penn A-4 & 34.7 & 51.3 & 63.7 & 65.0 & 58.7 & 63.3 \\
\hline Penncross & 46.7 & 61.0 & 65.0 & 66.3 & 63.0 & 67.0 \\
\hline B99061R & 40.3 & 54.7 & 63.3 & 64.3 & 57.3 & 62.3 \\
\hline ASR368 & 42.7 & 57.7 & 67.0 & 69.0 & 64.3 & 67.7 \\
\hline $\operatorname{LSD}_{(0.05)^{y}}$ & NS & NS & NS & NS & NS & NS \\
\hline $\mathrm{CV}$ & 12.6 & 10.3 & 9.4 & 8.3 & 12.0 & 10.1 \\
\hline
\end{tabular}

${ }^{2} 1 \mathrm{~cm}=0.3937$ inch.

${ }^{\mathrm{LSD}_{(0.05)}}=$ Fisher's protected least significant difference test at $P=0.05$.

${ }^{\mathrm{NS}}$ Nonsignificant according to $\mathrm{LSD}_{(0.05)} ; \mathrm{CV}=$ coefficient of variation.

Table 4. Relative growth as measured by percentage cover and turfgrass density of a glyphosate-resistant line of creeping bentgrass (ASR368), its non-transformed control (B99061R), and creeping bentgrass reference cultivars in Michigan from Apr. 2001 to Oct. $2001(\mathrm{n}=3)$.

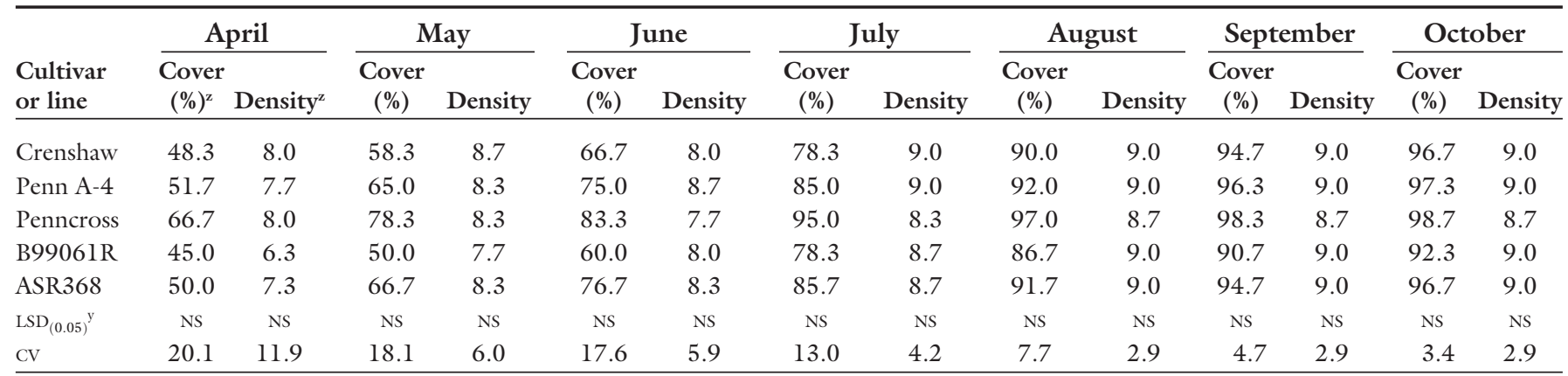

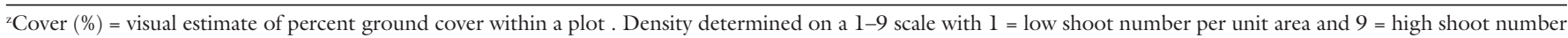
per unit area.

${ }_{\mathrm{LSD}_{(0.05)}}=$ Fisher's protected least significant difference test at $P=0.05$

NSNonsignificant according to $\mathrm{LSD}_{(0.05)} ; \mathrm{CV}=$ coefficient of variation. 
Table 5. Percentage ground cover and turfgrass density of a glyphosate-resistant line of creeping bentgrass (ASR368), its non-transformed control (B99061R), and creeping bentgrass reference cultivars in Ohio from May to Sept. 2001.

\begin{tabular}{|c|c|c|c|c|c|c|c|c|c|c|}
\hline \multirow{2}{*}{$\begin{array}{l}\text { Cultivar } \\
\text { or line }\end{array}$} & \multicolumn{2}{|c|}{ May } & \multicolumn{2}{|c|}{ June } & \multicolumn{2}{|c|}{ July } & \multicolumn{2}{|c|}{ August } & \multicolumn{2}{|c|}{ September } \\
\hline & Cover $(\%)^{\mathrm{z}}$ & Density $^{z}$ & Cover (\%) & Density & Cover (\%) & Density & Cover (\%) & Density & Cover (\%) & Density \\
\hline Crenshaw & $36.7 \mathrm{a}^{\mathrm{y}}$ & 5.3 & $43.3 \mathrm{a}$ & 6.3 & $53.3 \mathrm{a}$ & 6.7 & $36.7 \mathrm{a}$ & $5.0 \mathrm{a}$ & $58.3 \mathrm{a}$ & $5.7 \mathrm{a}$ \\
\hline Penncross & $37.7 \mathrm{a}$ & 5.3 & $33.3 \mathrm{ab}$ & 6.3 & $33.3 \mathrm{~b}$ & 6.7 & $36.7 \mathrm{a}$ & $4.0 \mathrm{ab}$ & $46.7 \mathrm{a}$ & $4.3 \mathrm{ab}$ \\
\hline B99061R & $27.0 \mathrm{ab}$ & 4.7 & $11.7 \mathrm{c}$ & 7.0 & $13.3 \mathrm{c}$ & 4.3 & $15.0 \mathrm{~b}$ & $2.7 \mathrm{bc}$ & $26.7 \mathrm{~b}$ & $3.3 \mathrm{~b}$ \\
\hline ASR368 & $26.7 \mathrm{ab}$ & 5.0 & $20.0 \mathrm{bc}$ & 7.0 & $23.3 \mathrm{bc}$ & 5.3 & $15.0 \mathrm{~b}$ & $2.0 \mathrm{c}$ & $26.7 \mathrm{~b}$ & $3.3 \mathrm{~b}$ \\
\hline
\end{tabular}

${ }^{2}$ Cover $(\%)=$ visual estimate of percent ground cover within a plot . Density determined on a $1-9$ scale with $1=$ low shoot number per unit area and $9=$ high shoot number per unit area.

${ }^{y}$ Means followed by the same letter are not significantly different according to Fisher's protected least significant difference test at $P=0.05$ [LSD $\left.{ }_{(0.05}\right]$.

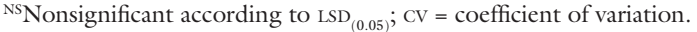

Table 6. Stolon length of a glyphosate-resistant line of creeping bentgrass (ASR368), its non-transformed control (B99061R), and creeping bentgrass reference cultivars in Oregon in Aug. and Nov. 2000. Means were calculated from the maximum and minimum values of three plugs per replicate $(n=9)$.

\begin{tabular}{|c|c|c|}
\hline Cultivar or line & August & November \\
\hline & \multicolumn{2}{|c|}{--- Stolon length $\left(\mathrm{cm}^{\mathrm{z}}\right)$--- } \\
\hline Crenshaw & 39.7 & 103.0 \\
\hline Penn A-4 & 40.7 & 101.7 \\
\hline Penncross & 49.7 & 111.3 \\
\hline B99061R & 42.7 & 106.3 \\
\hline ASR368 & 41.0 & 99.3 \\
\hline $\left.\operatorname{LSD}_{(0.05)}\right)^{\mathrm{y}}$ & NS & NS \\
\hline $\mathrm{CV}$ & 9.2 & 12.8 \\
\hline
\end{tabular}

display a distinct advantage in establishment, stolon vigor, plot colonization, plant development, or relative shoot density over its corresponding nontransformed tissue culture control, B99061R, or other reference cultivars (Table 5).

Table 7. Percent cover of a glyphosate-resistant line of creeping bentgrass (ASR368), its non-transformed control (B99061R), and creeping bentgrass reference cultivars in Oregon from Sept. 2000 to Mar. $2001(\mathrm{n}=3)$.

\begin{tabular}{|c|c|c|c|c|}
\hline \multirow[b]{2}{*}{ Cultivar or line } & \multicolumn{2}{|c|}{2000} & \multicolumn{2}{|c|}{2001} \\
\hline & September & October & February & March \\
\hline Crenshaw & 61.0 & 80.0 & 84.3 & 78.3 \\
\hline Penn A-4 & 63.3 & 76.7 & 88.7 & 82.7 \\
\hline Penncross & 74.3 & 94.3 & 92.3 & 90.7 \\
\hline B99061R & 54.3 & 76.7 & 87.0 & 88.3 \\
\hline ASR368 & 51.7 & 75.0 & 83.7 & 80.0 \\
\hline $\operatorname{LSD}_{(0.05)}{ }^{\mathrm{z}}$ & NS & NS & NS & NS \\
\hline $\mathrm{CV}$ & 21.4 & 18.3 & 9.6 & 9.4 \\
\hline
\end{tabular}

In Oregon, there were no significant differences in stolon vigor among creeping bentgrass lines on any date (Table 6). Percentage of cover was estimated after Aug. 2000 when plants within individual plots began growing together. No significant differences were detected in relative ability to colonize the plots during any of the eight observation dates from Sept. 2000 through Aug. 2001 (Tables 7 and 8). Significant differences in shoot density were only detected during July when 'Penn A-4' exhibited significantly higher shoot density than 'Crenshaw' and 'Penncross'. However, ASR368 was not significantly different from either the non-transformed tissue culture control or any of the commercial cultivars for relative shoot density at any measurement date.

\section{Conclusion}

Currently, creeping bentgrass is not considered an important weed of production agriculture and is considered a minor weed of pastures and naturalized areas (Banks et al., 2003;

Table 8. Percent cover and turfgrass density of a glyphosate-resistant line of creeping bentgrass (ASR368), its non-transformed control (B99061R), and creeping bentgrass reference cultivars in Oregon from May to Aug. 2001 (n = 3).

\begin{tabular}{|c|c|c|c|c|c|c|c|c|}
\hline \multirow[b]{2}{*}{ Cultivar or line } & \multicolumn{2}{|c|}{ May } & \multicolumn{2}{|c|}{ June } & \multicolumn{2}{|c|}{ July } & \multicolumn{2}{|c|}{ August } \\
\hline & Cover $(\%)^{\mathrm{z}}$ & Density $^{z}$ & Cover (\%) & Density & Cover $(\%)$ & Density & Cover (\%) & Density \\
\hline Crenshaw & 96.7 & 6.3 & 96.7 & 7.0 & 100.0 & $6.0 b c^{y}$ & 100.0 & 6.3 \\
\hline Penncross & 100.0 & 6.3 & 100.0 & 6.0 & 100.0 & $6.7 \mathrm{bc}$ & 100.0 & 6.3 \\
\hline B99061R & 99.3 & 7.0 & 99.3 & 7.3 & 100.0 & $7.7 \mathrm{a}$ & 100.0 & 8.0 \\
\hline ASR368 & 99.3 & 7.0 & 98.3 & 7.3 & 100.0 & $7.3 \mathrm{ab}$ & 100.0 & 6.7 \\
\hline
\end{tabular}

${ }^{2}$ Cover $(\%)=$ visual estimate of percent ground cover within a plot. Density determined on a $1-9$ scale with $1=$ low shoot number per unit area and $9=$ high shoot number per unit area.

${ }^{y}$ Means followed by the same letter are not significantly different according to Fisher's protected least significant difference test at $P=0.05$ [LSD ${ }_{(0.05)}$ ].

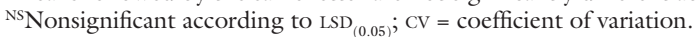


Shulte and Neuteboom, 2002). Several herbicides in addition to glyphosate are registered for control of creeping bentgrass in these situations (Butler, 2003; Colquhoun et al., 2001; Dant, 2005; Mueller-Warrant, 2003); however, the Roundup Pro label and other glyphosate-based herbicides promise only partial control of non-transgenic creeping bentgrass. In this research, plant establishment, stolon vigor, plot colonization, plant development, and turfgrass density of event ASR368 was not materially distinct from its non-transformed tissue culture control or from commercial non-transgenic cultivars under non-competitive unmanaged conditions at any location. The observed variability in creeping bentgrass lateral growth was less than that typically observed due to differences in climate and cultural practices, such as mowing, irrigation, and fertilization (Holt and Payne, 1951; Turgeon, 2002). These results agree with previous research conducted in turfgrass (Gardner et al., 2003, 2004) and for establishment of stolon nodes in non-competitive conditions (Williams et al., 2005) that demonstrate that glyphosate-resistant creeping bentgrass does not exhibit a novel phenotype that would make it more fit to occupy or become more invasive in unmanaged ecosystems or production agriculture than traditional creeping bentgrass.

\section{Literature cited}

Baker, H.G. 1965. Characters and modes of origin of weeds, p. 147-172. In: H.G. Baker and G.L. Stebbins (eds.). The genetics of colonizing species. Academic Press, New York.

Banks, P.A., B. Branham, K. Harrison, T. Whitson, and I. Heap. 2004. Determination of potential impact from the release of glyphosate- and glufosinate resistant Agrostis stolonifera L. in various crop and non crop ecosystems. 25 Mar. 2006. <http://www.wssa.net/society/bentgrass.pdf $>$.

Bergelson, J.C.B. Purrington, C.J. Palm, and J.C. Lopez-Gutierrez. 1996. Costs of resistance: A test using transgenic Arabidopsis thaliana. Proc. Royal Soc. London, Ser. B-Biol. Sci. 263:1659-1663.
Bradshaw A.D. 1958. Natural hybridization of Agrostis tenuis Sibth. and A. stolonifera L. New Phytologist 57:66-84.

Cattani, D.J., M.H. Entz, and K.C. Bamford. 1991. Tiller production and dry matter accumulation in six creeping bentgrass genotypes grown in Manitoba. Can. J. Plant Sci. 71:595-599.

Colquhoun, J., W. Brewster, C. MallorySmith, and R. Burr. 2001. Weed management in grass seed production. Oregon State Univ. Ext. Serv., EM 8788.

Dant, L. 2005. Control of glyphosateresistant creeping bentgrass with postemergence herbicides. 25 Mar. 2006. <http://turfgrass.hort.iastate.edu/pubs/ turfrpt/2005/pdf/Roundup.pdf>.

Dernoeden, P.H. 2000. Creeping bentgrass management: Summer stresses, weeds, and selected maladies. Ann Arbor Press, Chelsea, Mich.

Gardner, D.S., T.K. Danneberger, and E.K. Nelson. 2004. Lateral spread of glyphosateresistant transgenic creeping bentgrass lines in established turfgrass swards. Weed Technol. 18:773-778.

Gardner, D.S., T.K. Danneberger, E. Nelson, W. Meyer, and K. Plumley. 2003. Relative fitness of glyphosate resistant creeping bentgrass lines in kentucky bluegrass. HortScience 38:455-459.

Hart, S.E., F. Yelverton, E.K. Nelson, D.W. Lycan, and G.M. Henry. 2005. Response of glyphosate-resistant and glyphosatesusceptible bentgrass (Agrostis spp.) to postemergent herbicides. Weed Technol. 19:549-559

Hitchcock, A.S. 1950. Manual of the grasses of the United States. 2nd ed. (revised by A. Chase). U.S. Dept. Agr. Misc. Publ. 200.

Holt, E.C. and K.T. Payne. 1951. Variation in spreading rate and growth characteristics of creeping bentgrass seedlings. Agron J. 43:88-90.

James, C. 1997. Global status of transgenic crops in 1997. ISAAA Briefs No. 5. Intl. Serv. for the Acquisition of Agri-biotech Applications, Ithaca, N.Y.

James, C. 1998. Global status of transgenic crops in 1998. ISAAA Briefs No. 8. Intl. Serv. for the Acquisition of Agri-biotech Applications, Ithaca, N.Y.
Johnson, P.G. and T.P. Riordan. 1999. A review of issues pertaining to transgenic turfgrasses. HortScience 34(4):594-598.

Jonsdottir, G.A. 1991. Tiller demography in seashore populations of Agrostis stolonifera, Festuca rubra, and Poa irrigata. J. Vegetation Sci. 2:89-94.

Kendrick, D.L. and T.K. Danneberger. 2002. Lack of competitive success of an intraseeded creeping bentgrass cultivar into an established putting green. Crop Sci. 42:1615-1620.

Padgette, S.R., K.H. Kolacz, X. Delannay, D.B. Re, B.J. LaVallee, C.N. Tinius, W.K. Rhodes, Y.I. Otero, G.F. Barry, D.A. Eichholtz, V.M. Peschke, D.L. Nida, N.B. Taylor, and G.M. Kishore. 1995. Development, identification, and characterization of a glyphosate-tolerant soybean line. Crop Sci. 35:1451-1461.

Schulte, R.P.O. and J.H. Neuteboom. 2002. Advanced analysis of dry-weightrank data to discriminate direct and indirect interactions between white clover and grasses in a multi-species pasture under a range of management strategies. Grass Forage Sci. 57:113-123.

Thompson, G.A., W.R. Hiatt, D. Facciotti, D.M. Stalker, and L. Comai. 1987. Expression in plants of a bacterial gene coding for glyphosate resistance. Weed Sci. 35(1):19-23.

Turgeon, A.J. 2002. Turfgrass management, 6th ed. Prentice Hall, Englewood Cliffs, N.J.

U.S. Department of Agriculture. 2005. Creeping bentgrass perspective. 25 Mar. 2006. <http://www.aphis.usda.gov/ about-aphis/downloads/perspectiveCBGwp.pdf>.

Williams, D., P. Burrus, R. King, E.K. Nelson, and J. Frelich. 2005. Comparisons of glyphosate-tolerant and glyphosatesusceptible creeping bentgrass genotypes in tiller production from stolon fragments. Intl. Turf Soc. Res. J. 10:281-285. 